\title{
Distance between pollen donor and recipient influences fruiting success in slickspot peppergrass, Lepidium papilliferum
}

\author{
lan C. Robertson and Amy Colleen Ulappa
}

\begin{abstract}
Plant populations are often spatially structured owing to limited dispersal of pollen and seed. Mating between neighboring individuals in such populations often leads to reduced reproductive performance relative to matings between distant individuals. This response, which may be a result of inbreeding depression or prezygotic mating barriers, was investigated for slickspot peppergrass, Lepidium papilliferum L. (Brassicaceae), a rare insect-pollinated mustard endemic to sagebrush-steppe habitat in southwestern Idaho. Through hand pollination experiments we found that individual plants receiving pollen from distant sources (75-100 m and 6.5-20 km away) had significantly higher percent fruit sets than those relying on pollen from neighboring plants $(<1 \mathrm{~m}$ away). Self pollinated plants produced little or no fruit. These results suggest that L. papilliferum relies primarily, if not exclusively, on outcrossed pollination, and that its populations are spatially structured. Conservation efforts should therefore strive to protect sufficiently large areas of suitable habitat to ensure maintenance of genetic diversity and preserve or enhance connectivity between populations.

Key words: Brassicaceae, inbreeding, outbreeding, population spatial structure, rare species.

Résumé : A structure spatiale des populations végétales est souvent liée a une dispersion limitée du pollen et des graines. Dans de telles populations, le croisement entre individus contigus conduit souvent à des performances de reproduction réduites, comparativement à celles qui proviennent des croisements entre individus éloignés. Cette réaction pourrait résulter d'une faiblesse de consanguinité ou de barrières pré-zygotiques; les auteurs ont étudié cette question chez la lépidie papillée (Lepidium papilliferum L., Brassicaceae), une espèce rare de moutarde, endémique aux habitats de steppe à armoise du sud-ouest de l'Idaho. Suite à des pollinisations manuelles, les auteurs ont trouvé que les plantes individuelles recevant du pollen de sources distantes (éloignées de 75-100 m et 6,5-20 km), montrent un pourcentage de mise à fruit significativement plus élevé, comparativement à celles qui dépendent du pollen des plantes voisines $(<1 \mathrm{~m})$. Les plantes auto-fécondées produisent peu ou pas de fruits. Ces résultats suggèrent que le L. papilliferum s'appuie surtout, sinon exclusivement, sur la pollinisation extérieure, et que sa population est spatialement structurée. Les efforts de conservation devraient chercher à protéger des aires suffisamment vastes d'habitat approprié pour garantir le maintien de la diversité génétique, et assurer ou promouvoir la connectivité entre les populations.
\end{abstract}

Mots clés : Brassicaceae, auto-fécondation, fécondation croisée, structure spatiale des populations, espèce rare.

[Traduit par la Rédaction]

\section{Introduction}

Neighboring individuals in spatially structured plant populations often are more closely related to one another than to distant individuals owing to limited pollen flow and seed dispersal (Levin and Kerster 1974; Levin 1981; Waser and Price 1989, 1994). As such, the potential for outcrossing may have profound effects on a plant's reproductive success. Mating among close relatives, including selfing, may lead to a reduction in fecundity caused by shared self-incompatibility alleles of the parents or by an increase in homozygosity and expression of recessive deleterious alleles (Charlesworth and

Received 25 May 2004. Published on the NRC Research Press Web site at http://canjbot.nrc.ca on 7 December 2004.

I.C. Robertson ${ }^{1}$ and A.C. Ulappa. Department of Biology, Boise State University, 1910 University Drive, Boise, ID 83725, USA.

${ }^{1}$ Corresponding author (e-mail: iroberts@ boisestate.edu).
Charlesworth 1987; Lande 1995; Waser and Williams 2001). On the other hand, outcrossed pollination over large distances may cause reductions in fecundity owing to prezygotic rejection of distant pollen or breakup of locally adapted genotypes (Waser and Price 1989; Parker 1992; Montalvo and Ellstrand 2001; Waser and Williams 2001). Along the continuum from inbreeding to outbreeding, an optimal degree of outbreeding, where individual fitness is increased through avoidance of the deleterious effects of recessive alleles or through heterozygote advantage, is expected (Waser and Price 1983; Waser 1993).

Understanding the relationship between outcrossing distance and reproductive performance is of particular importance for rare and endangered species because any decrease in seed production can threaten the species' long-term viability (Ellstrand and Elam 1993; Byers 1998). Because rare plants typically occur in small populations that are vulnerable to local extinction due to a fixation of deleterious alleles (genetic risk of extinction) and to demographic factors (ecological risk of extinction), opportunities for outcrossing may 
be critical to ensure maintenance of genetic diversity within populations (Lande 1995). Adequate levels of genetic diversity and gene flow are generally viewed as essential because they provide for the long-term viability of a species in the face of environmental change (Ellstrand and Elam 1993; Lande 1995; Haig 1998).

Here we investigate how geographic distance between pollen source and recipient influences fruit production in slickspot peppergrass, Lepidium papilliferum L. (Brassicaceae), a rare plant endemic to sagebrush-steppe habitat in southwestern Idaho. Within sagebrush-steppe habitat the plant is limited to microsites known as "slick spots", which are characterized by their high levels of clay and salt as well as by subsurface water retention that is higher than that of surrounding areas (Quinney 1998). Currently only 60-70 sites are known to contain L. papilliferum, many of which support no more than several hundred individuals. A few sites support several thousand individuals, at least in years with favorable weather. Over the past century L. papilliferum has declined dramatically throughout its range because of habitat degradation attributed to exotic species invasions, wildfires, and anthropogenic disturbance (Moseley 1994). Twenty-one sites known from historical records dating back to 1892 are considered extirpated (Moseley 1994).

Lepidium papilliferum exhibits two distinct life history patterns. In plants with an annual life cycle, germination, flowering, and seed production occur within a single season. Those plants having a biennial life cycle persist as rosettes through the first year and flower and fruit the following year (Moseley 1994). Biennials are generally larger than annuals (approximately $15-30 \mathrm{~cm}$ in height versus $3-15 \mathrm{~cm}$ ) and produce much more seed; however, probability of survival to reproduction is often low for biennials because of overwinter mortality (Moseley 1994). The biological basis for the two life history patterns has not been determined, although phenotypic plasticity in response to microclimate is a likely explanation.

Recent studies suggest that $L$. papilliferum relies on outcrossed pollination mediated by insects (Robertson and Klemash 2003; Robertson 2004). The plant's small, white flowers, which occur on multiflowered inflorescences and bloom from late April to mid June, attract insects from several families of Hymenoptera (Apidae, Halictidae, Sphecidae, Vespidae), Coleoptera (Dermestidae, Meloidae, Melyridae), and Diptera (Bombyliidae, Syrphidae, Tachinidae), among others (Robertson and Klemash 2003). Once a flower has been pollinated, it develops a full-sized fruit within 2 weeks. Maturation of seed within the fruit takes several more weeks and concludes with the fruit dehiscing and releasing its seeds in late June or early July. Almost all mature fruits produce two seeds. Unpollinated flowers remain in bloom for several weeks before they wilt and die.

Although the genetic structure of L. papilliferum populations is not known, spatial structuring is likely because populations are typically small and separated from one another by at least several kilometers. Moreover, L. papilliferum fruits and seeds lack any obvious structures for long-distance dispersal (Moseley 1994). Given the plant's apparent reliance on outcrossed pollination (Robertson 2004), establishing the relationship between outcross proximity (i.e., distance between pollen source and recipient) and fruit production is necessary to provide insight into the mating system and population structure of L. papilliferum and may be an important step toward explaining variability in reproductive performance among populations. Through hand pollination of individuals with pollen obtained at different source distances, we examined whether outcross distance influences fruiting success in L. papilliferum. The results of our study are discussed in terms of their possible implications for conservation.

\section{Materials and methods}

From early May to mid July 2003, we conducted our study at three sites in southwestern Idaho containing L. papilliferum. Two sites, Powerline (PL) and Artillery (ART), were located $6.5 \mathrm{~km}$ apart within the Orchard Training Area (OTA) of the Idaho Army National Guard. The third site, Kuna Butte (KB), was located approximately $20 \mathrm{~km}$ southwest of the other sites. Intervening areas between our study sites included irrigated agriculture, grassland (primarily exotic species), and sagebrush-steppe habitat lacking slick spots inhabited by $L$. papilliferum. All three populations supported several hundred or more plants spread over a minimum of 15 slick spots per site, although exact counts of plants were not made.

At each of the three sites, we selected 25 plants for study, five plants from each of five slick spots. No effort was made to distinguish between annuals and biennials. Instead, we selected plants in similar condition that were approximately $7-12 \mathrm{~cm}$ in height, which could have been either annuals or small biennials given that growth was continuing. Prior to the onset of flowering, we placed a cylindrical insect-proof cage (constructed from 10-mm hardware cloth covered with fine $0.25-\mathrm{mm}^{2}$ white mesh) over each plant, thereby ensuring that flowers were not pollinated by visiting insects. A previous study found no effect of the cages on plant development or flowering (Robertson and Klemash 2003). Within each slick spot, the caged plants were assigned randomly to one of five groups: (1) control, (2) self pollination, (3) cross pollination with plant $<1 \mathrm{~m}$ away (nearest neighbor treatment), (4) cross pollination with plant 75-100 m away (between slick spot treatment), and (5) cross pollination with a plant from another study site (between population treatment). The experimental layout is illustrated in Fig. 1. We considered the three populations in our study, as well as the five slick spots in each population, to be independent of one another.

Experimental manipulations began once plants were in full bloom, approximately 2-3 weeks after we installed the cages. For the self-pollination treatment, we snipped a small inflorescence of opened flowers from the plant and then brushed it gently and thoroughly over all opened flowers on the same plant. For the cross-pollination treatments, we used a similar technique, except that the inflorescence used for pollination came from a different plant (i.e., a plant $<1 \mathrm{~m}$ away, 75-100 m away, or from another site, depending on treatment). As a sham operation for control plants and crosspollination plants, we snipped off a small inflorescence, just like in the self pollination treatment. To increase the number of flowers contacted during brush pollination, we repeated 
Fig. 1. Schematic representation of the experimental design. Squares represent the study sites (PL, ART, KB), circles represent individual slick spots, and numbers within circles represent the control and treatment groups within slick spots. Arrows show direction of pollen movement in the "between populations" treatment. Spatial relationships of slick spots within sites and caged plants within slick spots are not implied in the figure.

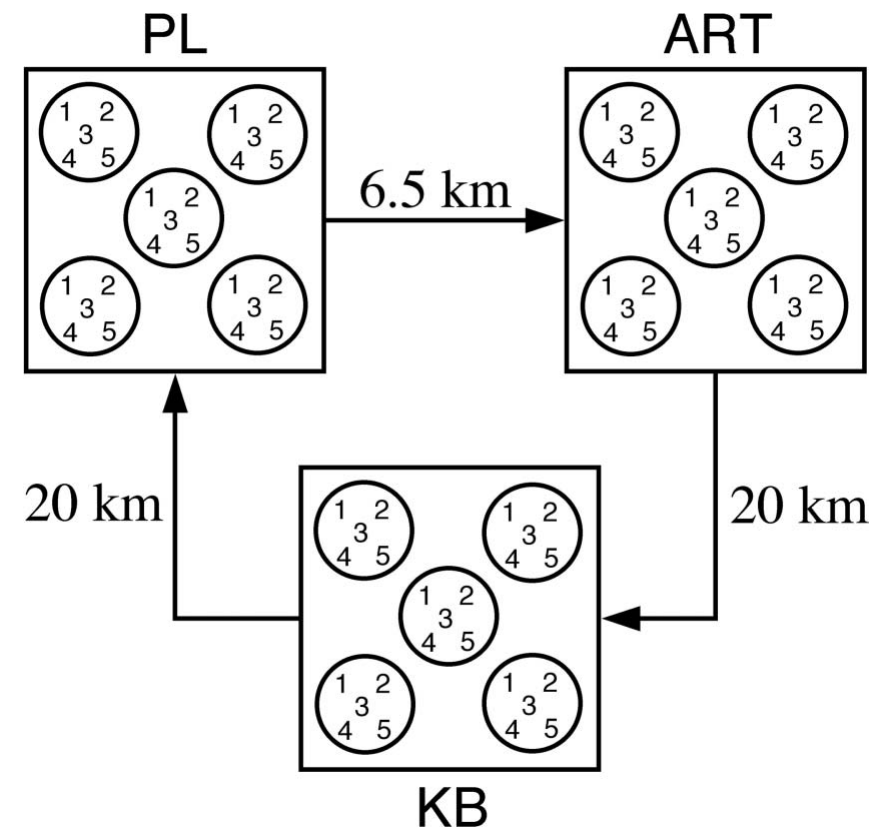

manipulations after 1 week. Once a plant ceased flowering, we determined its percent fruit set by collecting two to four inflorescences and counting the number of wilting flower pedicels (i.e., unpollinated flowers) and seed-bearing fruits. We included only the first 10 flowers on an inflorescence in the analysis, because later-opening flowers might have missed the experimental manipulation and thus caused us to underestimate fruiting success.

\section{Statistical analyses}

We fit a linear mixed model (Milliken and Johnson 1992) to the response, percent fruit set. The fixed effect was treatment, and the random effects were population, slick spot nested within population, and interactions with populations. Because some plants died during the course of the study, the data are not completely balanced with respect to treatments and populations. Therefore, we used a Satterthwaite's adjustment to the degrees of freedom in the test for the treatment effect. With a percentage outcome, it is important to ensure that the basic assumptions of the model have been met; therefore, we used Levene's test (Milliken and Johnson 1992) to assess equality of residuals among treatments and populations and the Wilks-Shapiro test (Zar 1999) to test for normality of residuals. To test for specific treatment differences, we compared each pair of differences and used a Tukey adjustment to control for the overall type-I error rate of 0.05. We conducted all our analyses using SAS 8.2. The mixed model was fit using Proc Mixed.

\section{Results}

Owing to the death of a few plants, sample sizes at the time of data collection ranged from 12 to 15 per group. This level of mortality during the flowering period is not unusual for L. papilliferum (Robertson, unpublished data) and was not confined to a specific treatment or site in our study. Consistent with the assumptions of the model, there was normality of residuals and equality of residuals across treatments $\left(W=0.981, P=0.376 ; F_{4,67}=1.99, P=0.107\right.$, respectively).

Tests for a population effect and a population by treatment interaction revealed essentially no variation in response among the three populations, indicating similar response to treatment in the three study sites (Table 1). Slick spots, nested within populations, showed a nonsignificant effect on percent fruit set (Table 1). However, there was a significant effect of treatment on percent fruit set (Table 1): percent fruit set increased as the distance between pollen donor and recipient increased (Fig. 2). Plants in the control and selfpollination treatment had low percent fruit sets and did not differ significantly from one another. The increase in percent fruit set between the selfing and nearest neighbor treatments was not statistically significant. However, when the pollen source was 75-100 $\mathrm{m}$ away, the increase in percent fruit set relative to self-pollinated plants was significant. Plants pollinated by their nearest neighbor had significantly lower percent fruit set than those pollinated by plants from other study sites. There was no statistical difference in percent fruit set between plants cross pollinated by a source 75$100 \mathrm{~m}$ away and those pollinated by plants from other study sites.

A closer examination of outcrossing distance in the between populations treatment revealed that percent fruit set was higher for the shorter outcrossing distance $(61.7 \pm 9.6 \%$ when pollen was moved $6.5 \mathrm{~km}$ versus $50.0 \pm 6.8 \%$ when pollen was moved $20 \mathrm{~km}$ ). However, this difference was not statistically significant ( $t$ test: $t=0.99$, df $=13, P=0.34$ ).

\section{Discussion}

Our study confirms a separate finding by Robertson (2004) that L. papilliferum relies primarily, if not exclusively, on cross pollination for successful fruit production; percent fruit set was higher in cross-pollinated plants than in self-pollinated plants. The presence of some fruit in the control and self-pollination treatment suggests either that L. papilliferum is capable of limited amounts of self pollination, or that insects found their way into a few cages and cross pollinated some of the flowers. We view the latter possibility as more likely for several reasons. First, small insects known to carry $L$. papilliferum pollen have occasionally been found within cages (personal observations over several years of study), leading to the possibility of cross pollination. Second, a number of plants in the control and self pollination treatment produced no fruit, which would seem unlikely if selfing is possible for this species. Third, based on the morphology of L. papilliferum flowers, as well as on numerous direct observations of flowers during our study, there is no indication that pollen laden anthers come in contact with stigmas. While it is possible that mechanical shaking or wind might have caused pollen to reach stigmas on the same plant, we noted that the cages served as effective barriers against wind. Finally, although the genus Lepidium 
Table 1. Mixed model analysis results.

\begin{tabular}{lcllr}
\hline Random effect & Estimate & SE & $Z$ value & $P$ value \\
\hline Population & 28.18 & 70.91 & 0.4 & 0.345 \\
Slickspot (population) & 108.93 & 72.71 & 1.5 & 0.067 \\
Treatment $\times$ population & 29.30 & 49.59 & 0.59 & 0.277 \\
Residual & 282.43 & 63.75 & 4.43 & $<0.001$ \\
\hline Fixed effects & Numerator df & Denominator $\mathrm{df}$ & $F$ value & $P$ value \\
\hline Treatment & 4 & 7.72 & 12.68 & 0.002 \\
\hline
\end{tabular}

Fig. 2. Mean percent fruit set $( \pm S E)$ as a function of control and treatment. Different letters above bars represent statistically significant differences between groups (Tukey test, $P<0.05$ ). Numbers at the base of bars indicate sample size. SP, self pollination; NN, nearest neighbor pollination; BSS, between slick spots pollination; BP, between populations pollination.

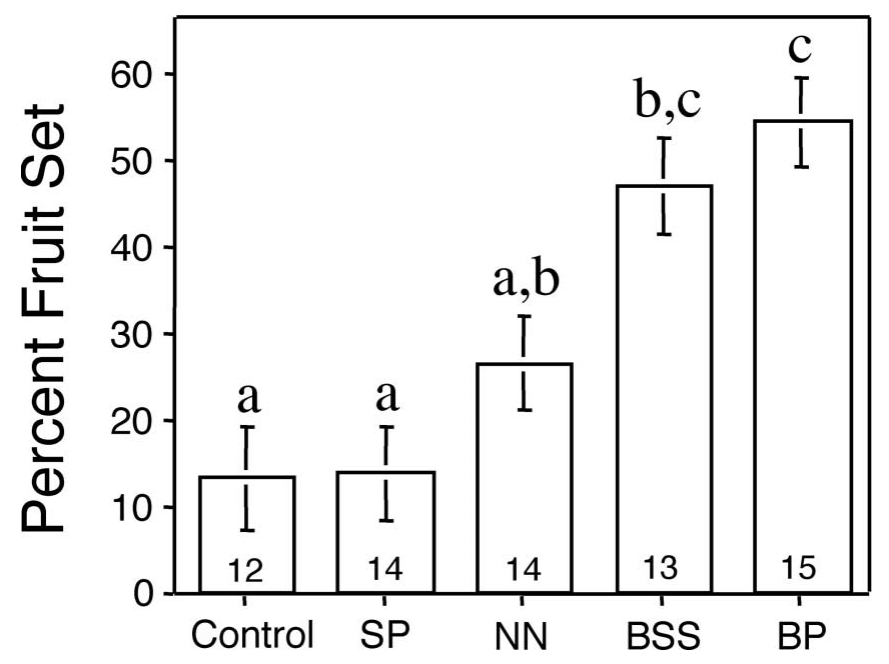

does include a number of species that are self compatible, these species, unlike L. papilliferum, typically have reduced floral structures (J.L. Bowman, 2002, personal communication). Thus, although self pollination can not be ruled out for L. papilliferum, its contribution to reproduction appears limited at best.

Consistent with the hypothesis that L. papilliferum populations are spatially structured, plants receiving pollen from distant sources had higher percent fruit sets than those relying on pollen from neighboring plants. Because L. papilliferum lacks any obvious mechanism for longdistance fruit or seed dispersal, it seems likely that neighboring plants are more closely related to one another than they are to more distant individuals. Thus, our results may indicate inbreeding depression as a consequence of matings between related neighbors in structured populations. Alternatively, a physiological mechanism that reduces selfing or other forms of inbreeding (i.e., a partial self-incompatibility system) may exist (Waser 1993). Before a case for inbreeding depression can be made, it will be necessary to determine the genetic structure of $L$. papilliferum populations, as well as to examine the fitness consequences of inbreeding beyond measurements of percent fruit set, such as fruit size, germination success, and offspring vigor. Nevertheless, the pattern we have uncovered is a strong indication that nearby mating (i.e., which likely involves mating with genetically similar individuals) has deleterious consequences for reproductive success in L. papilliferum.

Population structure and reduced fecundity through inbreeding are of critical importance for rare species because their populations tend to be small and opportunities for outcrossing are often limited (Lande 1988; Ellstrand and Elam 1993; Byers 1998; Lande 1995). Studies have shown that the scale of population structure and the extent of its influence on reproduction varies between species. For example, Gentiana pneumonanthe, a rare perennial, exhibits inbreeding depression with selfing and hybrid vigor between populations, but shows no effect of donor distance within populations (Oostermeijer et al. 1995). By contrast, seed set in Hymenoxys herbacea, another rare species, increases over outcrossing distances of 3-10 m but not at greater distances (Moran-Palma and Snow 1997). In L. papilliferum, percent fruit set increased with donor distance within populations, suggesting a genetic structure among slick spots within these populations. This result suggests that, in addition to limited seed dispersal, pollen movement mediated by insects may be concentrated within slick spots. Indeed, a leptokurtic pattern of pollen movement is typical for insect-pollinated plants (Levin and Kerster 1974; Godt and Hamrick 1993). Over the past several years, our observations of insect movement on L. papilliferum have revealed that insects often linger on individual plants or within slick spots. Some pollinators, such as melyrid beetles, confine most of their movements within individual plants and likely contribute little to pollination and fruit production (Robertson 2003). Other insects (see Robertson and Klemash (2003) for a list) move more freely within and between slick spots (I.C. Robertson, personal observation), and thus may serve as important agents of gene flow within and possibly between populations.

The extent to which insect pollinators carry pollen between populations remains an open question for L. papilliferum, as it does for most plant-pollinator systems due to the difficulties associated with documenting longdistance insect movement and pollen transfer (Godt and Hamrick 1993; Proctor et al. 1996; but see Schulke and Waser 2001). An alternative approach, which we are currently pursuing in an effort to quantify gene flow, is to use molecular techniques to examine the amount and spatial distribution of genetic variability within and among populations (Williams and Waser 1999). Such data will help clarify the role of insects as dispersers of pollen within and among L. papilliferum populations.

While our results indicate a reduction in fecundity with inbreeding, we cannot make a similar inference concerning outbreeding. Although percent fruit set was lower when outcrossing distance was $20 \mathrm{~km}$ than when it was $6.5 \mathrm{~km}(50 \pm$ $6.8 \%$ vs. $61.7 \pm 9.6 \%$ ), the difference was not statistically 
significant and our sample size was inadequate for a definitive comparison. Outbreeding depression, which may result from disruption of local adaptation, has been found in several plant species (Price and Waser 1979; Waser et al. 2000; Montalvo and Ellstrand 2001) but not in others (Sobrevila 1988; Byers 1998; Luijten et al. 2002). As Waser et al. (2000) point out, the spatial scales over which outbreeding depression may arise likely depend on the spatial and temporal scale of gene flow and of change in selective regimes in the environment. Establishing these parameters for L. papilliferum, as well as conducting additional longdistance outcrossing experiments with larger sample sizes, may shed light on whether local adaptation has occurred within populations or subsets of populations.

In summary, the variation in percent fruit set associated with outcrossing distance indicates that L. papilliferum populations are structured. Conservation of $L$. papilliferum should therefore include protection and maintenance of suitable habitat for large populations because each population likely consists of numerous subpopulations. Effective population size may be increased by ensuring connectivity between populations. Unfortunately, no information is currently available about how distance between populations influences insect-mediated pollen flow in L. papilliferum. A population that becomes isolated risks losing genetic diversity that is normally maintained via outcrossing. If genetic analyses reveal that certain populations have become isolated, the introduction of new genotypes from neighboring populations should be considered, although caution in this approach is warranted (for a discussion of the pros and cons of genotype translocation, see Montalvo and Ellstrand (2001); Luijten et al. (2002); Hufford and Mazer (2003)). Ultimately, preserving suitable habitat for pollinating insects, as well as ensuring the maintenance and enhancement of connectivity between $L$. papilliferum populations, will be essential for the plant's long-term viability.

\section{Acknowledgements}

Financial support for the project was provided by grants from the Idaho Bureau of Land Management, Idaho Army National Guard, and Boise State University. Earlier drafts of the manuscript benefited from the comments of Stephanie Billinge, Marlene Gast, Wilma Robertson, and Amy Stillman. Laura Bond assisted with the statistical analysis. We thank Hollie Leavitt and Danielle Klemash for their help in the field, as well as Ann DeBolt, Marjorie McHenry, Dana Quinney, Roger Rosentreter, and Jay Weaver for their ongoing interest and support for this research.

\section{References}

Byers, D.L. 1998. Effect of cross proximity on progeny fitness in a rare and a common species of Eupatorium (Asteraceae). Am. J. Bot. 85: 644-653.

Charlesworth, D., and Charlesworth, B. 1987. Inbreeding depression and its evolutionary consequences. Annu. Rev. Ecol. Syst., 18: $237-268$.

Ellstrand, N.C., and Elam, D.R. 1993. Population genetic consequences of small population size: Implications for plant conservation. Annu. Rev. Ecol. Syst. 24: 217-242.
Godt, M.J.W., and Hamrick, J.L. 1993. Patterns and levels of pollen-mediated gene flow in Lathyrus latifolius. Evolution, 47: 98-110.

Haig, S.M. 1998. Molecular contributions to conservation. Ecology, 79: 413-425.

Hufford, K.M., and Mazer, S.J. 2003. Plant ecotypes: Genetic differentiation in the age of ecological restoration. Trends Ecol. Evol. 18: 147-155.

Lande, R. 1988. Genetics and demography in biological conservation. Science (Washingon, D.C), 241: 1455-1460.

Lande, R. 1995. Mutation and conservation. Conserv. Biol. 9: 782 791.

Levin, D.A. 1981. Dispersal versus gene flow in plants. Ann. Mo. Bot. Gard. 68: 233-253.

Levin, D.A., and Kerster, H.W. 1974. Gene flow in seed plants. Evol. Biol. 7: 139-220.

Luijten, S.H., Kery, M., Oostermeijer, J.G.B., and den Nijs, H.C.M. 2002. Demographic consequences of inbreeding and outbreeding in Arnica montana: A field experiment. J. Ecol. 90: 593-603.

Milliken, G.A., and Johnson, D.E. 1992. Analysis of messy data. Vol. 1. Designed experiments. Chapman and Hall, New York.

Montalvo, A.M., and Ellstrand, N.C. 2001. Nonlocal transplantation and outbreeding depression in the shrub Lotus scoparius (Fabaceae). Am. J. Bot. 88: 258-269.

Morán-Palma, P., and Snow, A.A. 1997. The effect of interplant distance in mating success in federally threatened, selfincompatible Hymenoxys herbacea $=H$. acaulis var. glabra (Asteraceae). Am. J. Bot. 84: 233-238.

Moseley, R.K. 1994. Report on the conservation status of Lepidium papilliferum. Conservation Data Center, Idaho Department of Fish and Game, Biose, Idaho.

Oostermeijer, J.G.B., Altenburg, R.G.M., and den Nijs, H.C.M. 1995. Effects of outcrossing distance and selfing on fitness components in the rare Gentiana pneumonanthe (Gentianaceae). Acta Bot. Neerl. 44: 257-268.

Parker, M.A. 1992. Outbreeding depression in a selfing animal. Evolution, 46: 837-841.

Price, M.V., and Waser, N.M. 1979. Pollen dispersal and optimal outcrossing in Delphimium nelsoni. Nature (London), 227: 294 297.

Proctor, M., Yeo, P., and Lack, A. 1996. The natural history of pollination. Timber Press, Portland, Oreg.

Quinney, D. 1998. LEPA (Lepidium papilliferum). Report available from the Military Division, Idaho Army National Guard, 4040 West Guard Street, Biose, ID 83707, USA.

Robertson, I.C. 2003. Insect-mediated pollination of Lepidium papilliferum: 2003. Unpublished report available from the Military Division, Idaho Army National Guard, 4040 West Guard Street, Biose, ID 83707, USA.

Robertson, I.C. 2004. Importance of outcrossing for fruit production in slickspot peppergrass, Lepidium papilliferum L. (Brassicaceae). West. North Am. Nat. 64: 265-268.

Robertson, I.C., and Klemash, D. 2003. Insect-mediated pollination in slickspot peppergrass, Lepidium papilliferum L. (Brassicaceae), and its implications for population viability. West. North Am. Nat. 63: 333-342.

SAS Institute Inc. 1999. SAS/STAT user's guide, version 8. SAS Institute, Cary, N.C.

Schulke, B., and Waser, N.M. 2001. Long-distance pollinator flights and pollen dispersal between populations of Delphinium nuttallianum. Oecologia, 127: 239-245.

Sobrevila, C. 1988. Effects of distance between pollen donor and recipient on fitness components in Espeletia schultzii. Am. J. Bot. 82: 1186-1198. 
Waser, N.M. 1993. Population structure, optimal outbreeding, and assortative mating in angiosperms. In The natural history of inbreeding and outbreeding: Theoretical and empirical perspectives. Edited by N.W. Thornhill. University of Chicago Press, Chicago. pp. 173-199.

Waser, N.M., and Price, M.V. 1983. Optimal and actual outcrossing in plants, and the nature of plant-pollinator interaction. In Handbook of experimental pollination biology. Edited by C.E. Jones and R.J. Little. Van Nostrand Reinhold, New York. pp. 341-359.

Waser, N.M., and Price, M.V. 1989. Optimal outcrossing in Ipomopsis: seed set and offspring fitness. Evolution, 43: 10971109.

Waser, N.M., and Price, M.V. 1994. Crossing distance effects in Delphinium nelsonii: outbreeding depression and inbreeding depression in progeny fitness. Evolution, 48: 842-852.
Waser, N.M., Price, M.V., and Shaw, R.G. 2000. Outbreeding depression varies among cohorts of Ipomopsis aggregata planted in nature. Evolution, 54: 485-491.

Waser, N.M., and Willams, C.F. 2001. Inbreeding and outbreeding. In Evolutionary ecology: Concepts and case studies. Edited by C.W. Fox, D.A. Roff, and D.J. Fairbairn. Oxford University Press, New York. pp. 84-96.

Williams, C.F., and Waser, N.M. 1999. Spatial genetic structure of Delphinium nuttallianum populations: inferences about gene flow. Heredity, 83: 541-550.

Zar, J.H. 1999. Biostatistical analysis, 4th ed. Prentice-Hall, Upper Saddle River, N.J. 